АНАЛИЗА УЧЕСТАЛОСТИ ОБОЛЕВАҢА ОД МАЛИГНИХ БОЛЕСТИ НА ТЕРИТОРИЈИ ПЧИЫСКОГ ОКРУГА У ПЕРИОДУ ОД 2000. ДО 2010. ГОДИНЕ

Ержика Антић ${ }^{1}$, Марија Накић², Драгиња Стошић

\title{
ANALYSIS OF THE INCIDENCE FOR CANCER IN THE TERRITORY OF PČINJ DISTRICT IN THE PERIOD SINCE 2000. UNTIL 2010.
}

Eržika Antić, Marija Nakić, Draginja Stošić

\section{Сажетак}

Увод. После болести срияа и крвних судова, малигне болести представљају најчешћи узрок оболевања и умирања људи, како у свету, тако и у нашој земли.

Циљ. Циљ овога рада је приказ учесталости оболевана од малигних болести у Пчиъском округу од 2000. до 2010. године.

Метод. За проиену учесталости оболевана од малигних болести на подручју Пчињског округа коришћен је број новооболелих од малигних болести и стандардизована стопа инциденције по полу и по водећим локализацијама. Извршено је и поређене оболевања од малигних болести са Колубарским округом, Браничевским округом и Централном Србијом на основу стандардизованих стопа на 100.000 cmaновника.

Резултати. Оболевање од малигних болести у Пчиьском округу има тенденцију пораста. Код мушкараца највећи пораст оболевања је у 2010. години, док је код жена у 2009. години. У поређењу са другим регионима, у 2000. години број оболелих од малигних болести био је најмањи у Пчињском округу. У 2010. години Пчињски регионје, са 31,3 оболеле жене од кариинома грлића материце на 100.000 жена, и 84,3 оболела мушкариа од кариинома плућа на 100.000, на првом месту у односу на посматране регионе.

\section{Summary}

Introduction. After cardiovascular diseases, malignant diseases are the leading cause of death and morbidity of mhe people in the world and in our country.

Objective. The objective of this study was to review the incidence of diseases such as malignant disease in Pčinja district in the period 2000-2010 year.

Methods. To assess the incidence of malignant diseases in Pčinja district, we used the number of new cases of cancer and standardized incidence rates by sex and leading localization. Were carried out and comparison of morbidity from malignant disease of Kolubara District, Braničevski District and Central Serbia based on standardized rates per 100.000 population.

Results. Morbidity of malignant disease in Pcinja district tends to increase. In men, the largest increase of diseases was in 2010 year, while in the women in the 2009 year. Compared with other regions, in 2000, the number of patients with malignant disease was lowest in Pčinja district. In 2010 Pčinja region with 31.3 women suffering from cervical cancer per 100.000 women and 84.3 men suffering from lung cancer per 100.000, is in the first place compared to the observed regions.

\footnotetext{
${ }^{1}$ Др сц. мед. прим. Ержика Антић, специјалиста социјалне медицине, субспецијалиста здравственог васпитања.

2 Др Марија Накић, специјалиста социјалне медицине.

${ }^{3}$ Драгиња Стошић, специјалиста здравствене статистике и информатике.
} 
Закључак. Да бисмо смањили оболевање од малигних болести, неопходна је свеобухватна мобилизачија друштва усмерена на превентабилне факторе ризика која би уз јачање и унапређење система здравствене заштите довела до ефикасније контроле малигних болести.

Кључне речи: малигне болести, оболевање, Пчињски округ.
Conclusion. In order to reduce morbidity from malignant disease, it is necessary that comprehensive social mobilization be directed at preventable risk factors, also with the strengthening and improvement of the health care system would lead to more efficient control of malignant disease.

Key words: malignant disease, illness, Pčinja district.

\section{УВОД}

$\mathrm{M}$ алигне туморе, или малигне неоплазме, чини група болести различите локализације, морфологије, клиничке слике и прогнозе, која се карактерише прогресивним и неконтролисаним растом структурално и функционално измењених ћелија, разарањем ткива у коме су настале и каснијим метастазирањем, тј. расејавањем малигних ћелија путем крви и лимфе у друге (удаљене) органе. ${ }^{(1)}$

После болести срца и крвних судова, малигне болести представљају најчешћи узрок оболевања и умирања људи како у свету тако и у нашој земљи. Према подацима Светске здравствене организације, преко 22 милиона људи у свету живи са раком. Сваке године у свету се региструје 11 милиона новооболелих, од чега $60 \%$ у земљама у развоју, док седам милиона умре од малигних болести.

Сваке године у Републици Србији се дијагностикује око 32.000 нових случајева малигних болести, а годишње од рака у Републици Србији умре око 20.000 људи. Најчешће малигне болести код жена у Србији су рак дојке, рак дебелог црева и рак грлића материце. Код мушкараца најчешће малигне болести су рак плућа и рак дебелог црева.
Због високе учесталости малигних обољења и њихове високе стопе смртности, превенција малигних болести је од великог јавно-здравственог значаја и представља најефикаснији приступ њиховој контроли. На више од $80 \%$ свих малигних болести могуће је утицати спречавањем или модификовањем фактора ризика, тј. спречавањем почетка болести а, уколико до болести ипак дође, исход је могуће побољшати раним откривањем, терапијом и рехабилитацијом. ${ }^{(2)}$

\section{ЦИЉ РАДА}

Циљ овога рада је приказ учесталости оболевања од малигних болести у Пчињском округу од 2000. до 2010. године.

\section{МЕТОД РАДА}

За процену учесталости оболевања од малигних болести на подручју Пчињског округа коришћен је број новооболелих од малигних обољења и стандардизована стопа инциденције по полу и по водећим локализацијама. Подаци су преузети из Регистра за рак централне Србије, из Извештаја о инциденцији и морталитету од малигних болести у Централној Србији. (3) Извршено је и поређење оболевања од малигних болести са Колубарским округом (Западна Србија), Браничевским округом (Источна Србија) и Централном Србијом 
на основу стандардизованих стопа на 100.000 становника. Критеријуми за избор ових округа били су сличност у површини и броју становника, као и НАТО агресија у 1999. години на ова подручја. Пчињски округ се налази на југоистоку Србије и има

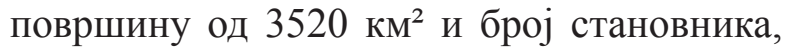
по процени за 2010. годину, 227.554 становника. Општине Пчињског округа су: Босилеград, Бујановац, Прешево, Сурдулица, Трговиште, Владичин Хан и Врање.

\section{РЕЗУЛТАТИ}

У Пчињском округу у 2000. години било је 527 новооболелих од малигних болести свих локализација, и то 290 мушкараца и 237 жена, док је тај број у 2010. години износио 861, и то 468 мушкараца и 393 жене (Табела 1). Евидентан је пораст оболевања од малигних болести и то како код мушкараца тако и код жена. Код мушкараца највећи пораст оболевања је у 2010. години, док је код жена у 2009. години.

Табела 1. Број новооболелих од малигних болести по полу, Пчиюски округ, 2000-2010.

\begin{tabular}{|l|l|l|l|l|l|l|l|l|l|l|l|}
\hline Година & 2000. & 2001. & 2002. & 2003. & 2004. & 2005. & 2006. & 2007. & 2008. & 2009. & 2010. \\
\hline Мушкарци & 290 & 322 & 330 & 356 & 371 & 412 & 366 & 374 & 404 & 466 & 468 \\
\hline Жене & 237 & 272 & 290 & 302 & 296 & 352 & 364 & 329 & 313 & 404 & 393 \\
\hline Укупно & 527 & 594 & 620 & 658 & 667 & 764 & 730 & 703 & 717 & 870 & 861 \\
\hline
\end{tabular}

Извор: Регистар за рак Централне Србије.

У циљу објашњења разлога пораста вредности показатеља оболевања од малигних болести у Пчињском округу у посматраном периоду, анализиране су и стандардизоване стопе на 100.000 становника за све локализације и извршено поређење са другим регионима. На пример, стандардизована стопа на 100.000 становника за све локализације за мушкарце у Колубарском и Пчињском округу у 2000. години износила је 218,1, односно 197,9 оболелих, у Браничевском 215,1 оболео, а у Централној Србији 258,3 оболела мушкарца.

У 2010. години у Пчињском округу већ имамо 287,2 оболела, у Браничевском 254,7 оболелих, у Колубарском 302,6 оболелих, а у Централној Србији 291,8 оболелих на 100.000 становника (мушкарци). Значи, у Пчињском округу има више оболелих него у Браничевском и то за 32,5 оболелих на 100.000 становника, а мање него у Колубарском за 15,4 оболела, и у односу на Централну Србију мање за 4,6 оболелих на 100.000 становника за особе мушког пола (Графикон 1).
Графикон 1. Стандардизоване стопе на 100.000 становника, у периоду 2000-2010. године, за све локализацчје, муикаричи.

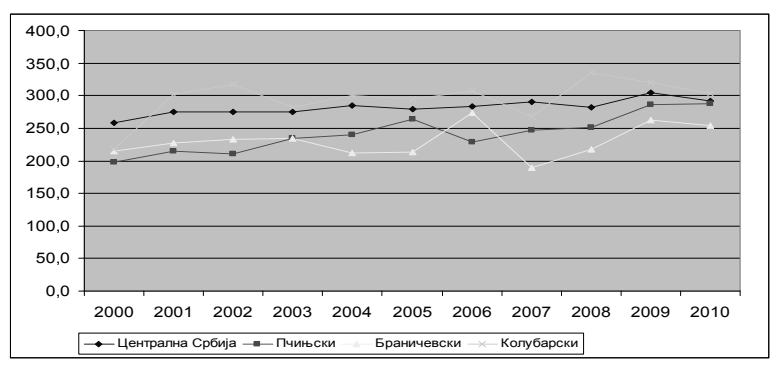

Стандардизована стопа на 100.000 становника код свих локализација за особе женског пола у Пчињском округу износила je 153,4 оболеле жене, у Колубарском округу 181,3 оболеле, а у Централној Србији 228,7 на 100.000 становника у 2000. години.

Већ у 2010. години у Пчињском округу број оболелих жена износио је 224, у Колубарском 259,9, у Браничевском 201,8, a у Централној Србији 250,9 оболелих жена на 100.000 становника, односно у Пчињском округу је више оболелих жена него у Браничевском округу за 22,2 жене, а мање него у Колубарском округу за 35,9 и мање у односу на Централну Србију за 26,9 жена (Графикон 2). 
Графикон 2. Стандардизоване стопе на 100.000 становника, у периоду 2000-2010. године, за све локализације, жене.

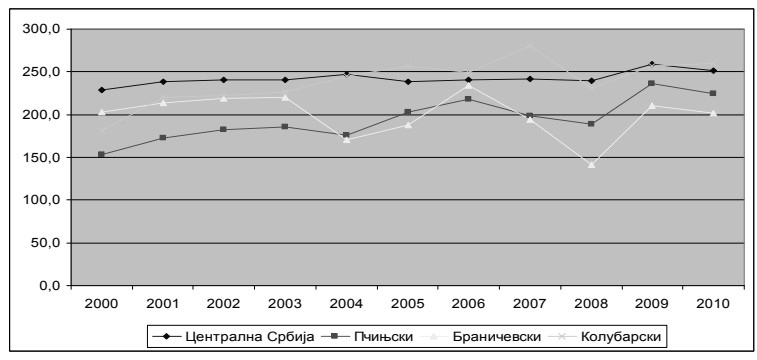

Приметно је да је у нултој години, тј. у 2000. години, број оболелих од малигних болести био најмањи у Пчињском округу, док је у Колубарском, Браничевском и у Централној Србији тај број био већи у просеку за 42 оболела на 100.000 становника.

Број оболелих од малигних болести у Пчињском округу је, уз извесне варијације, у порасту. Стандардизована стопа на 100.000 становника за све локализације за мушкарце у 2000. години износила је 197,9 оболелих, док је у 2005. износила чак 264 оболела, након пада у 2006. години, број оболелих поново расте до 287,2 на 100.000 мушкараца, колико је износио у 2010. години. Жене мање оболевају од малигних болести од мушкараца, тако да су у 2000. години биле 153,4 оболеле жене, а у 2007. години 198,1 оболела, а у 2009. години 236,1 оболела на 100.000 жена (Графикон 3).

\section{Графикон 3. Стандардизоване стопе} инщиденције од малигних тумора према полу, Пчињски округ, 2000-2010. године.

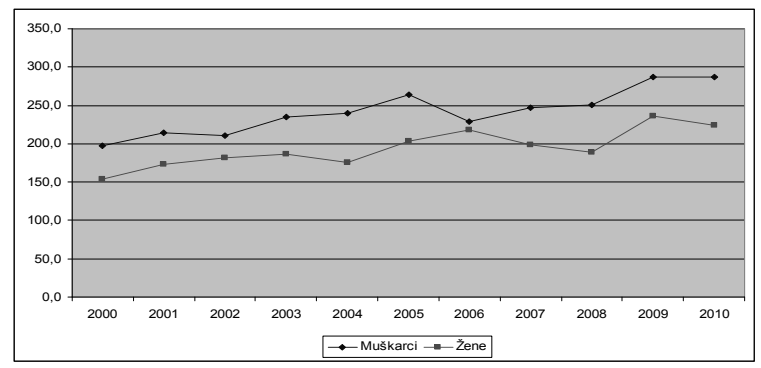

Рак дојке је најучесталија локализација малигног процеса у особа женског пола у Пчињском округу (Графикон 4).
Стандардизоване стопе од малигних тумора дојке од 2000. до 2010. године имале су тенденцију пораста, и то у свим регионима, али ипак Пчињски регион је испод Централне Србије, Браничевског и Колубарског округа са 33,3 оболеле жене на 100.000 жена у 2000. години. У Пчињском региону у 2010. години било је више оболелих жена у односу на Браничевски, а мање у односу на Централну Србију и Колубарски регион (Графикон 5).

Графикон 4. Стандардизоване стопе на 100.000 становника за 5 најчешћих локализаиија малигних обољења код жена у Пчињском округу.

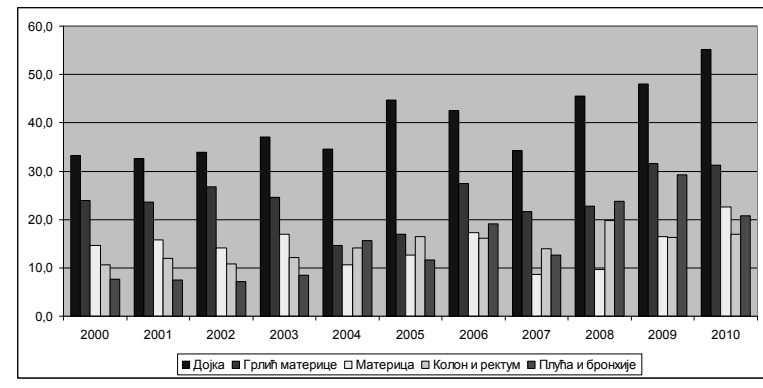

Графикон 5. Стандардизоване стопе оболеваға од рака дојке, жене, 2000-2010. године.

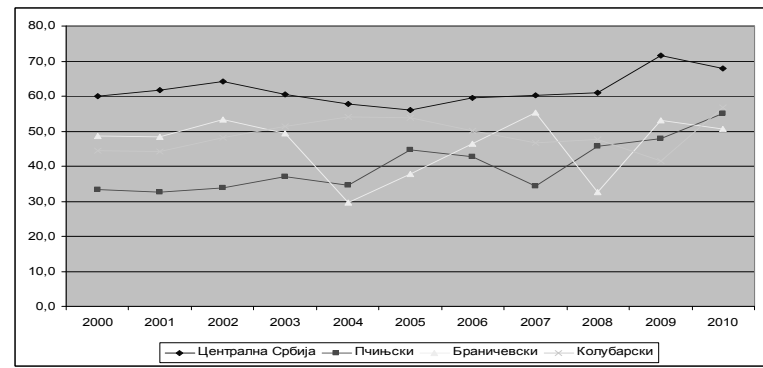

На високом другом месту налази се рак грлића материце са 23,9 оболелих, одмах после Колубарског региона, који има 13,9 оболелих, а мање је оболелих од жена Браничевског округа и Централне Србије. Међутим, у 2010. години Пчињски регион са 31,3 оболеле жене на 100.000 има највећи број оболелих жена у односу на посматране округе (Графикон 6). 
Графикон 6. Стандардизоване стопе оболевања од рака грлића материие, 2000-2010. године.

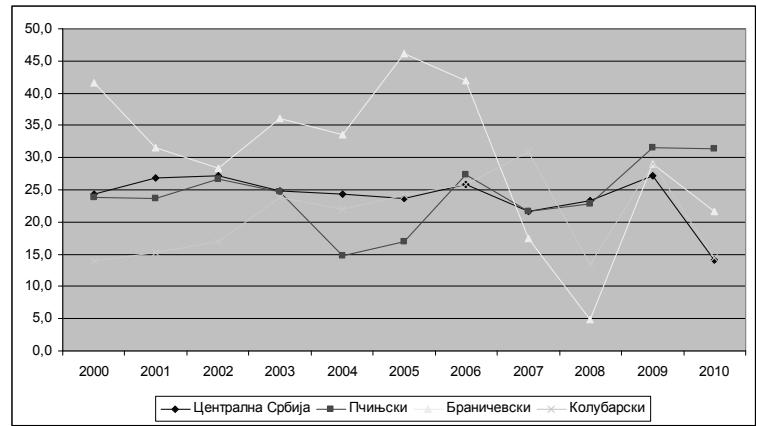

На трећем месту налазе се малигна обољења материце, затим колона и ректума, и плућа и бронхија.

Малигни тумори плућа, укључујући трахеју и бронхије, најучесталија су локализација малигних обољења код мушкараца (Графикон 7). Евидентно је и повећање броја оболелих жена у Пчињском округу од карцинома плућа (Графикон 4).

Графикон 7. Стандардизоване стопе на 100.000 становника за 5 најчешћих локализачија малигних обољења код мушкараиа у Пчињском округу.

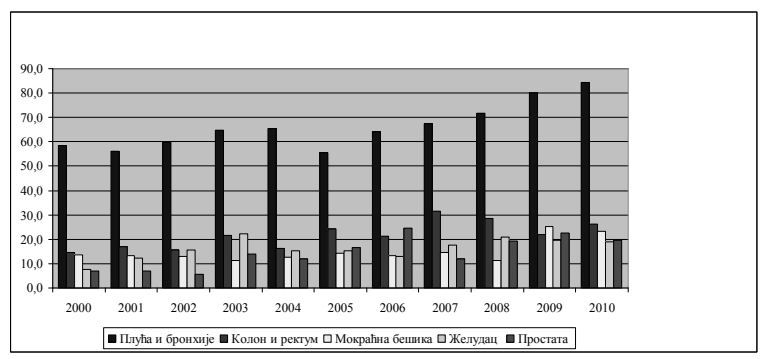

На територији Пчињског округа стандардизоване стопе оболевања од малигних болести плућа од 2000. до 2010. године имале су тенденцију пораста. Упоређујући са осталим регионима у 2010. години, Пчињски регион је на првом месту (Графикон 8). Следеће најчешће локализације малигних болести код мушкараца у Пчињском округу јесу колон и ректум, мокраћна бешика, желудац и простата, као и у другим регионима.
Графикон 8. Стандардизоване стопе оболевања од рака плућа, мушкарии, 2000-2010. године.

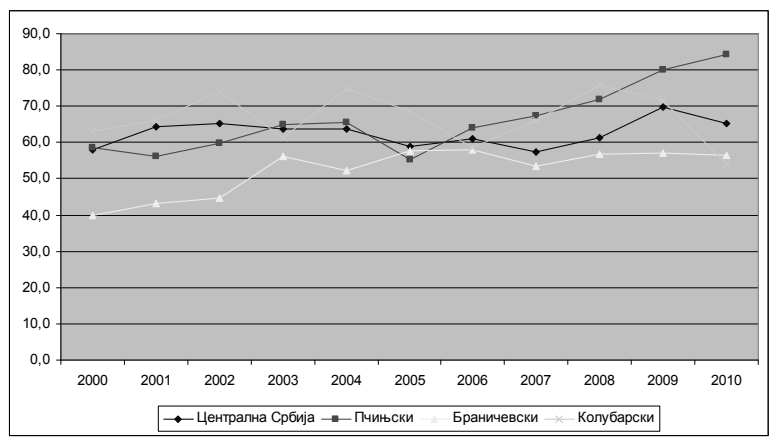

\section{ДИСКУСИЈА}

При тумачењу промена у оболевању и умирању од рака у дужем периоду треба имати на уму да стопе инциденције зависе и од промена у дијагностици, а на морталитетне стопе утиче и успешност лечења. Учесталост оболевања од малигних болести на територији Пчињског округа у посматраном периоду показује тенденцију пораста. Разлог ове појаве треба тражити и у квалитетнијој дијагностици, квалитетнијем пријављивању новооболелих од малигних обољења од стране здравствених установа и квалитетнијим подацима на потврди о узроку смрти. Поред тога, стопа инциденције (новооболелих) повећана је у многим земљама услед старења становништва. Процењује се да ће до 2020. године у свету од рака оболети 15 милиона становника, од којих ће $60 \%$ живети у земљама са недовољним ресурсима, како за превенцију, тако и за терапију ових обољења. ${ }^{(1)}$

Посматрајући Пчињски регион, не сме се изоставити чињеница да су поједина подручја овог округа у току НАТО бомбардовања 1999. године гађана осиромашеним уранијумом. Оболевању и умирању од малигних болести доприноси и висока учесталост фактора ризика и непрепознавање ризичног понашања и недовољно коришћење позитивних искустава у спровођењу програма превенције и раног откривања малигних тумора из развијенијих европских земаља. 
На основу постојећих знања о факторима ризика могуће је превенирати настанак малигних болести. Земље чланице Европске заједнице су 1985. године покренуле заједнички програм под називом „Европа против рака“" са циљем да до 2000. године смање морталитет од рака у наведеном региону за 15\%. Захваљујући кампањама које су се спроводиле у овим земљама, пре свега антипушачким, скринингу (рака грлића материце, дојке и колоректума) и активностима у промоцији здравља, смртност од рака је смањена у просеку за $9 \% .^{(4)}$

Сагледавањем улоге фактора ризика у настанку малигних обољења, може се уочити да је најзначајнији појединачни фактор ризика за настанак малигних тумора пушење, чије се учешће у етиологији рака процењује на 30\%. Фактори исхране учествују са око $35 \%$, затим следе инфекције са 10 до 15\%, репродуктивно и сексуално понашање $7 \%$, занимање 3-4\%, алкохол $3 \%$, геофизички фактори, јонизујуће и нејонизујуће зрачење $3 \%$, аерозагађење $1 \%$, јатрогени чиниоци $1 \%$, и други, још увек непознати фактори.

Већина тумора плућа узрокована је пушењем ${ }^{(5)}$, па је контрола употребе дувана приоритетна мера која се не односи само на мушкарце, већ и на жене. Карцином плућа је на првом месту код мушкараца и када је оболевање и када је умирање у питању, али је евидентно и повећање броја оболелих жена од карцинома плућа у Пчињском округу. Поред пушења, ризик је повећан и у току излагања азбесту, никлу, арсену, радону и јонизујућем зрачењу.

Рак дојке је најучесталија локализација и водећи узрок смрти код особа женског пола у Пчињском округу. Најзначајнија улога у настанку рака дојке приписује се хормонским и репродуктивним факторима. Високе дозе јонизујућег зрачења у периоду развоја дојки и менструације, као и гојазност после менопаузе, такође, повећавају ризик за појаву малигних тумора. Успех терапије зависи од стадијума малигне промене па се посебан значај придаје раном откривању. Увођење мамографије, која представља метод избора за рану детекцију рака дојке код жена старијих од 50 година, могло би да редукује ризик умирања за $24 \%{ }^{(6)}$

Рак грлића материце, након увођења скрининг програма, више не представља јавно-здравствени проблем за већину земаља Европе, што није случај код нас. Међутим, у току посматраног периода евидентан је пораст, нарочито када је оболевање у питању, и то повећање стандардизоване стопе од три пута. Најзначајнији узрок је инфективни агенс. Одређени типови хуманог папилома вируса преносе се сексуалним контактом и доводе до инфекције, која се код већине спонтано санира, а код малог броја жена прогредира у рак. Већи број сексуалних партнера и рани почетак сексуалних односа повећава ризик за појаву обољења. Скрининг се показао као ефикасна мера и када је у питању колоректални карцином и јасно је да постоји потреба за организованим скрининг програмом. ${ }^{(7)}$ Колоректални карцином спада у водеће локализације и када је оболевање и умирање у питању код оба пола. Деловање на факторе ризика, као што су неправилна исхрана, недовољна физичка активност и гојазност, могло би да смањи инциденцију и морталитет од колоректалних карцинома. ${ }^{(7)}$

Из овога се намеће да је потребно унапредити и очувати здравље кроз смањење изложености факторима ризика или кроз позитивно понашање. Процењује се да би примарна превенција могла да спречи настанак чак две трећине случајева рака.

Активности примарне превенције би требало да обухватају:

- здравствено просвећивање становништва,

- превенцију пушења,

- унапређење исхране, промоцију физичке активности и превенцију гојазности, - превенцију инфекција значајних за настанак малигних болести, 
- превенцију и заштиту од прекомерног излагања ултраљубичастим зрачењима,

- заштиту од канцерогених агенаса у животној и радној средини.

\section{ЗАКЉУЧАК}

Повећање учесталости оболевања од малигних болести, у посматраном периоду, како за особе мушког пола, тако и женског, указују на то да малигне болести, како у свету, тако и у Пчињском региону, представљу велики јавно-здравствени проблем. Да бисмо постигли напредак у борби против рака, неопходна је свеобухватна мобилизација усмерена на превентабилне факторе ризика, која би уз јачање и унапређење система здравствене заштите, довела до ефикасније контроле малигних болести.

\section{ЛИТЕРАТУРА}

1. Гледовић 3.,и сар.: Епидемиолигија. Медицински факултет Универзитета у Београду. Београд, 2009.

2. Национални програм Србија против рака. Министарство здравља Републике Србије. Београд, 2009.

3. Инциденција и морталитет од рака у централној Србији, 2000-2009. Регистар за рак централне Србије. Институт за јавно здравље Србије. Београд, 2010. 4. Здравље становника Србија.

Аналитчка студија здравља становника,
1997-2007. Институт за јавно здравље Србије. Београд, 2008.

5. Monographs on the Evaluation of Carcinogenic Risk to Humans. Tobacco Smoke and Involuntary Smoking. IARC. France, Lyon. 2004, Vol 83.

6. Michell MJ. Brest cancer screening. European Journal of Cancer Prevention 2005; Vol(14): 497-592.

7. Faivre J. Dancourt V. et al. Reduction in colorectal cancer mortality by fecal occult blood screening in a French controlled study. Gastroenterology 2004; 126(7): 1674-1680.

Контакт: Др Марија Накић, Завод за јавно здравље Врање, ул. Ј.Ј. Лунге бр. 1, Врање, 017421 310, e-mail: zzjzvr@open.telekom.com 